\title{
The Return Variability and Dispersion: Evidence from Mutual Funds in Post-Transition Countries
}

\author{
Dariusz Filip \\ Cardinal Stefan Wyszynski University in Warsaw (UKSW), Poland \\ Faculty of History and Social Sciences \\ UI. Wóycickiego 1/3, 01-938 Warszawa \\ E-mail: d.filip@uksw.edu.pl
}

\begin{abstract}
The purpose of the paper is to evaluate the performance of mutual funds operated in selected post-transition countries and to analyse their return variability and dispersion. The study sample consists of 294 equity funds (domestic and foreign ones) from the Czech Republic, Hungary and Poland. By using classic measures of return as well as popular measures of risk, it was possible to examine if equity funds from the CEE countries possess the ability to outperform. It was observed that funds generally obtained mean returns, which were below the corresponding benchmark. In most cases, however, the results were statistically insignificant. Fund returns compared to equity indices were characterised by lower ups and downs, especially during significant market changes. The analysis of performance variability and dispersion showed that there are entities which achieve marginally better return than their competitors at a relatively low risk level. The test for equality of variances applied in the study revealed evidence for the heterogeneity of return variabilities, which could be caused by sample selection bias.
\end{abstract}

Keywords: mutual funds, performance, risk, return evaluation, CEE countries

JEL classification: G11, G23, G29

\section{Introduction}

The mutual fund industries in post-transition countries, particularly the ones located in Central-Eastern Europe (CEE), are characterized by moderate dynamics, which allows for sustainable development of the financial sector. However, this growth is generally determined by economic situation. The asset management industries in the European emerging markets grew significantly over the last decade. According to the European Fund and Asset Management Association (EFAMA, 2016), the value of assets of the Czech investment fund industry at the end of the time horizon of the study amounted to EUR 7,818 million, which in comparison to 2005 (EUR 4,661 million) means an increase by $67 \%$. The value of Hungarian UCITS and non-UCITS funds increased from 7,757 million in 2005 to 18,105 million in 2015 (a 133\% growth). The assets under management of the Polish investment fund industry were valued at EUR 61,539 million in 2015 and at EUR 15,876 million in 2000, which means a $288 \%$ increase.

There has been a growing interest in these financial intermediaries in the recent years, which resulted in an increased demand on various rankings, analyses and reports concerning mutual funds. All these studies use a wide 
variety of tools for the appraisal of effectiveness and risk. Apart from the traditional approaches of comparing unit prices in subsequent periods, of including risk and market factors or of employing contemporary methods for measuring the level of managerial skills, the portfolio analysis makes also use of graphic evaluation tools. One of them is risk-performance mapping, which derives from the modern portfolio theory pioneered by Markowitz (1952) and allows for collating the expected return with a given risk level.

During their operation period, mutual funds are evaluated in terms of effectiveness (e.g. by comparing their performance with the benchmark) and in terms of investment risk level. In general, examining the effects of asset management is particularly significant while verifying the efficient-market hypothesis; this, in turn, allows for explaining possible outperformance. Hence, it might be assumed that perhaps it is possible for funds to outperform in the seemingly less efficient markets of small size, the CEE markets being an example. In view of the observations mentioned above, a research into the discussed CEE markets offers a significant contribution to the existing literature, especially as there is a serious lack of studies relating to emerging European markets. Moreover, the addressed issue seems to be important not only from the cognitive but also practical point of view. The returns achieved by individual mutual funds might have an impact on investment decisions by participants and suggest the possible potential for efficient asset management. The financial institutions, in turn, may use the fact of possessing appropriate effectiveness attributes in market play and media coverage.

The purpose of this article is to evaluate the effectiveness of mutual funds by collating the achieved rates of return with the risk levels in funds. Furthermore, the return dispersion analysis with particular emphasis on differences in return variability will be essential. The study is an introduction to the effectiveness evaluation of funds operated in the CEE countries and provides a basis for further surveys and analyses in this area.

The rest of the paper proceeds as follows. Firstly, the selected empirical literature on the effects of asset management by mutual funds, with a special focus on local markets, will be reviewed in section 1 . The methodological part of the paper (section 2) presents the applied data, describes the measures of return and risk level and research approaches used in the study. In Section 3, we discuss and interpret the empirical results. The final section 4 summarizes the major findings.

\section{Conceptual Issues and a Brief Literature Review}

One of the subjects regularly addressed by the financial literature on mutual fund industries is the evaluation of asset management effects achieved by financial intermediaries. The authors of major studies of the issue (e.g. Treynor, 1962; Sharpe, 1964; Lintner, 1965; Mossin, 1966) formulated the capital asset pricing model (CAPM), which is used to explain the crosssectional differences in returns, and determined the ways of measuring risk on securities (e.g. Merton, 1972; Friend and Blume, 1975). These findings allowed for establishing tools for measuring mutual fund performance. The 
early studies by Carlson (1970) and by Kon and Jen (1979) suggested that mutual funds may be unable to generate abnormal returns, among others due to management fees and other expenses. However, further studies (e.g. Ippolito, 1989; Goetzmann and Ibbotson, 1994) indicate the ability of funds to systematically generate positive results that underwrite the costs or even exceed them. These conclusions seem to be in the minority, though. Due to constraints (e.g. a survivorship bias documented by Brown et al., 1992; Elton et al., 1996) in reporting outperformance, the subsequent studies tried to explain returns by fund attributes or managerial characteristics.

More recent papers provide new tools for measuring return (e.g. Ferson and Schadt, 1996; Modigliani and Modigliani, 1997) or new empirical approaches (e.g. Huij and Verbeek, 2007; Kosowski et al., 2007). Consequently, within the financial literature concerning the effectiveness of performance, some studies take into account the specialist skills possessed by fund managers, which allow them to beat the market (e.g. Switzer and Huang, 2007; Naidenova et al., 2015). There are also papers devoted to return dispersion of mutual funds and its measures (e.g. de Silva et al., 2001; Ankrim and Ding, 2002]. In general, the ambiguity of findings results from the incomparability of time horizons under study, the contents of samples, the measures of return used and the empirical approaches adopted.

Most of the findings mentioned above relate to the US market; in the regional literature, the investment fund industry is not a popular topic. One of the first papers concerning mutual funds from developing countries has been written by Kaminsky et al. (2001). Having analysed the investments in emerging markets by financial intermediaries, e.g. in transition economies of the 1990s, they found that mutual funds invested in Europe were mostly the funds invested in the Czech Republic, Hungary and Poland. However, during the crisis within the mentioned period, the outflows of fund assets were large in the majority of the emerging markets. Another important study on this subject, written by Khorana et al. (2005), examined the size of 56 mutual fund industries from around the world and revealed the spread of development tendencies from the US to non-US industries. Especially the increase in the market share of assets under management was remarkable. Apart from the industry size, they also analysed its age, legal and regulatory factors, the experience of investors, and so forth. They also found out that the size of mutual fund industries had strong implications for post-transition economies.

The better-known studies addressing the issue of individual mutual funds relate to the Polish market (Swinkels and Rzezniczak, 2009; Białkowski and Otten, 2011). In the first one, the performance of equity, balanced, and bond funds was evaluated in relation to selectivity and market-timing skills of their managers. The time horizon of the study was the 2000-2007 period, i.e. the period directly preceding the onset of the global financial crisis. The results obtained by Swinkels and Rzezniczak confirmed the existence of positive but insignificant selectivity skills in the limited sample (38 funds). As for markettiming, there have been no similar findings. The second of the mentioned studies, the one by Białkowski and Otten (2011), used a considerably larger sample of 140 mutual funds. By means of Carhart's measure, they found that 
Polish equity, bond and mixed funds might not have been able to achieve abnormal returns in the 2000-2008 period. However, the domestic funds outperformed their foreign peers. Moreover, the study revealed performance persistence, which is a particularly valuable finding, especially with regard to winning funds. A less-known paper worth mentioning is the one by Olbryś (2009), in which she compares the market-timing and selectivity abilities of 15 Polish equity funds in the 2003-2009 period. The study, which used the unconditional Treynor-Mazuy model to evaluate market-timing skills, reported no significant evidence for outguessing the market. Moreover, the other of the adopted approaches, the conditional Ferson-Schadt model, turned out to be not very useful for evaluating the performance of Polish funds.

The mutual funds functioning in Hungary are described relatively rarely. Erdős and Ormos (2009) performed the evaluation of asset management effects by means of an original measure of return, the so-called daily recalculated monthly returns. In their study of 20 Hungarian open-ended mutual funds operated in the 2000-2007 period, they adopted a single index model within a global approach to performance analysis. Filip (2014), in turn, tried to establish whether the returns of Hungarian mutual funds - including equity, mixed, bond and money market funds - are influenced by survivorship bias. On the basis of discrete returns and Jensen's alphas calculated for the 20002012, he noted an insignificant influence of survivorship bias on the returns of surviving funds. Bóta and Ormos (2013), in turn, analysed a sample of 30 mutual funds invested in Hungary, Central and Eastern Europe or more developed markets. In order to measure performance, they used the intercepts from the Carhart four-factor model. The study period from 2001 to 2013 was divided into bearish and bullish periods. They found no significant excess returns. In the countries where the industry is still emerging and the number of funds is low, the empirical research in this area is undertaken very rarely. The performance of Czech mutual funds was analysed by Fajtová (2004) and Filip (2011). The first of the mentioned studies examined the performance of 24 closed-end funds from the perspective of market fluctuation and legislative changes in the 1996-2001 period. By means of rates of returns, market-adjusted returns and alphas from the one-factor CAPM model, she found the evidence for informational efficiency in the Czech mutual fund market. Filip (2011), in turn, tried to evaluate the performance of 14 openended funds, classified as equity funds, in the 2004-2010 period. By means of logarithmic rates of return, Jensen alphas and Carhart's measures, he obtained slightly abnormal but insignificant returns. He also noted that the possible outperformance is related to the limited performance persistence in consecutive periods and to market factors.

Within the financial literature on other post-transition economies, there are several popular papers. One of them is the study by Podobnik et al. (2007), who examined the efficiency of fund managers in the South-East European countries. Following the performance analysis of 14 Croatian, 14 Slovenian and 9 Bosnian mutual and investment funds using Sharpe ratio, Treynor ratio, information ratio, appraisal ratio, Jensen's alpha and Treynor-Mazuy coefficient, they were able to rank the funds. However, the results did not 
indicate that the funds possessed market-timing and selection abilities. Jargic et al. (2007), in turn, evaluated the performance of 9 Slovenian mutual funds. By means of Sharpe ratio, Treynor ratio, Jensen alpha, appraisal ratio, Beta coefficient and $\mathrm{R}^{2}$ coefficient estimated for the 2000-2003 period, they found that the analysed funds outperformed the market because they were well diversified and possessed efficiency characteristics. Also Markovic-Hribernik and Vek (2013) conducted the performance analysis for Slovenian mutual funds for the 2005-2009 period. The study used risk-adjusted measures (Modigliani-Modigliani ratio, Treynor ratio, Sortino ratio and information ratio) as well as models for measuring managerial abilities (Jensen's alpha and Treynor-Mazuy coefficient) and examined 9 funds with the "energy" investment policy. The authors, however, did not find stock selection and market-timing abilities of managers operating mutual funds in Slovenia.

The last of the reviewed studies concerns, among others, a few countries from the CEE region. On the basis of a vast number of performance measures such as Sharpe ratio, Treynor ratio, Jensen's alpha, Modigliani-Modigliani ratio, Fama-French measure and Carhart's measure, Lemeshko and Rejnuš (2015) were able to analyse open-end equity mutual funds on the sample of 27 emerging economies of the world; the time horizon of the study was the 20002014 period. They found that the examined mutual funds, including the ones from the CEE countries, are usually characterized by constant underperformance (the observation was made for the bearish as well bullish periods). The equity funds from the CEE emerging economies turned out to be among the most sensitive and prompt responding to macroeconomic changes.

Apart form the papers mentioned above, there are scarcely any well-known papers concerning mutual fund industries in post-transition countries. Future studies should include longer time spans and use multifaceted approaches or new measures of returns. However, the financial markets in new European Union (EU) member states, particularly in the CEE ones, are still perceived as less efficient. Even though the studies discussed above concluded, in general, that the analysed funds achieve returns below the benchmark, there is a need of further investigations in this area.

\section{Data and Methodology}

The choice of tools for measuring the effects of mutual fund asset management was made based on the review of empirical literature. The tools comprise a set of ratios for return appraisal as well as measures of risk levels in portfolios. Furthermore, Section 3 presents the scope of data and describes empirical methods used in this study.

\subsection{The Scope and Sources of Data}

The study analyses open-ended mutual funds operating in the Czech Republic, Hungary and Poland. The database constructed for the purposes of a broader project consists of the monthly values of assets under management per unit share. The measurement of return and risk level were conducted in yearly periods. The data come from the organizations collecting information about 
mutual funds in the Czech Republic (AKAT ČR), Hungary (BAMOSZ) and Poland (Analizy Online). The number of equity funds under study is presented in table 1.

Table 1 The number of equity funds included in the study

\begin{tabular}{|c|c|c|c|c|c|c|c|c|c|c|c|c|c|c|c|c|}
\hline Years & & & & & & & & & & & & & $\mathbf{Y}$ & $m$ & $\Delta$ & n \\
\hline $\begin{array}{l}\text { Number } \\
\text { of funds }\end{array}$ & ก & ำ & ก & i & ก & ก & ก & ก & i & ก & ก & ํำ & i & ก) & ก & S \\
\hline $\begin{array}{l}\text { Czech } \\
\text { Republic }\end{array}$ & 9 & 18 & 22 & 17 & 15 & 14 & 14 & 18 & 22 & 26 & 26 & 27 & 25 & 25 & 28 & 32 \\
\hline Hungary & 25 & 26 & 32 & 33 & 32 & 32 & 34 & 38 & 47 & 61 & 77 & 93 & 136 & 129 & 132 & 109 \\
\hline Poland & 10 & 12 & 13 & 16 & 17 & 20 & 26 & 38 & 58 & 79 & 89 & 107 & 118 & 135 & 143 & 153 \\
\hline
\end{tabular}

Source: Own compilation

Due to the length limitations of this paper, the performance analysis was done for the funds that invest their assets in domestic as well as foreign stock markets. It should be noted that the number of entities in the selected segment of funds is still relatively low, particularly in the Czech Republic. Hence, we decided not to divide equity funds into uniform groups. The next potential bias in the data collection may be the lack of distinction between the investment strategies (passive or active) adopted by funds. The time horizon of the study is the 2000-2015 period. Its beginning is related to the fact of possessing a sufficient amount of data concerning the analyzed industries; its end is the moment when the database was completed. In order to examine performance over various market periods, we divided the time horizon into subperiods referring to smaller stock market cycles.

\subsection{Characteristics of Performance Evaluation's Measures}

The measures for performance evaluation of mutual funds include return ratios and the measures of risk. The measurement employed in this study use the asset unit values. Due to the shortage of relevant databases in the CEE countries that would contain information about management fees, for example, the applied performance calculation totally omits the expense ratio in fund returns. Hence, all of the measures used are fee-unadjusted. Firstly, probably one of the simplest ratios is discrete return. It shows the rate of return on a unit of initial investment and can be expressed with the following formula:

$$
r_{i, t}=\frac{U P_{i, t}-U P_{i, t-1}}{U P_{i, t-1}}
$$

where $r_{i, t}$ is the discrete return of fund $i$ in period $t, U P_{i, t}$ and $U P_{i, t-1}$ are the unit prices of fund $i$ at the end $(t)$ and at the beginning $(t-1)$ of the analysed period. 
The rate of return calculated this way is then deducted form benchmark return, which is a stock exchange index. The market-adjusted return allows for finding the rate of income exceeding the benchmark. The presented measure of returns is defined as follows (Lee et al., 2008):

$r m_{i, t}=r_{i, t}-r_{m, t}$

where $\mathrm{rm}_{i, t}$ is the market-adjusted return of fund $i$ in period $t ; r_{m, t}$ is the return on the local equity market benchmark in period $t$.

The measures mentioned above ignore the differences in the risk level in funds. These differences are shown by reward-to-volatility ratio in the form of unsystematic risk (measured by standard deviation). The popular Sharpe's measure is calculated as follows (Sharpe, 1966):

$S R_{i, t}=\frac{r_{i, t}-r_{f, t}}{\sigma\left(r_{i, t}\right)}$

where $S R_{i, t}$ is the Sharpe ratio on fund $i$ in period $t ; r_{i, t}$ is the mean rate of return achieved over period $t$ by fund $i ; r_{f, t}$ is the mean risk-free return over the analogous period; $\sigma\left(r_{i, t}\right)$ is the standard deviation of the rate of return on fund $i$ in period $t$. The mean rates of return and standard deviation are calculated on the basis of monthly observations.

The modern portfolio theory uses the CAPM model to estimate the expected return, which is a linear function of systematic risk and managerial skills. One of the measures showing abnormal returns is an intercept of regression models including the achieved returns and market risks. Thus, for each mutual fund included in the database, we estimated a model from the following formula (Jensen, 1968):

$r_{i, t}-r_{f . t}=\alpha_{i}+\left(r_{m, t}-r_{f, t}\right) \beta_{i}+\varepsilon_{t}$

where $\alpha_{i}$ is abnormal return of fund $i$ (the so-called Jensen's alpha); $\beta_{i}$ is a systematic risk value of fund $i$ and $\varepsilon_{t}$ means a random error in period $t$. The estimations of $\alpha_{i}$ coefficient were conducted on the basis of monthly observations. The list of benchmarks used in the study is presented in table 2.

The data concerning return on investment without risk come from the International Financial Statistics quarterly reports published by International Monetary Fund. The values of main local market indices - PX, BUX and WIG were taken form Prague Stock Exchange, Budapest Stock Exchange and Warsaw Stock Exchange respectively. 
Table 2 The list of benchmarks for estimating the intercepts of CAPM models

\begin{tabular}{|c|c|c|}
\hline Country & Benchmark & Risk-free rates \\
\hline Czech Republic & PX & $\begin{array}{c}\text { Average rate weighted by volume, } \\
\text { on the three-month T-bills sold at auctions }\end{array}$ \\
\hline Hungary & $B U X$ & $\begin{array}{c}\text { Weighted average yield on } 90 \text {-day T-bills } \\
\text { sold at auctions }\end{array}$ \\
\hline Poland & WIG & $\begin{array}{c}\text { Weighted average yield on 13-week T-bills } \\
\text { sold at auctions }\end{array}$ \\
\hline
\end{tabular}

Source: Own compilation

The ratios representing risk level in funds constitute a counterbalance to the ways of measuring returns. One of the measures most frequently referred to in the financial literature is standard deviation, also known as the measure of unsystematic risk. The measure of volatility is calculated on the basis of the well-known formula (e.g. Isotalo, 2014):

$S D_{i, t}=\frac{\sqrt{\sum_{i=1}^{n}\left(r_{i, t}-\bar{r}_{i}\right)^{2}}}{n-1}$,

where $S D_{i, t}$ means standard deviation of fund $i$, and $n$ is the number of included periods. The measure allows for evaluating the historical variability of investment. It also shows the deviations of fund return from the mean value of return in a given period.

The performance of funds included in the sample was examined in yearly perspective. In the case of dispersion analysis, we compared the average annual returns on individual funds over the total period of their operating.

\subsection{Description of Empirical Methods}

In order to evaluate the effects of asset management and analyze the variability of returns, we will use two methodological approaches. Firstly, we will examine the differences between two populations of means in order to compare returns of mutual funds with the benchmark. This will be possible by the application of the Welch's $t$-test, according to the following formula [Welch, 1947]:

$$
t=\frac{\overline{r_{\text {fund }}}-\overline{r_{m}}}{\sqrt{\frac{S D_{\text {fund }}}{n_{\text {fund }}}-\frac{S D_{m}}{n_{m}}}}
$$

where $\overline{r_{\text {fund }}}$ and $\overline{r_{m}}$ are means of returns in the samples of funds and benchmark, respectively, $S D_{\text {fund }}$ and $S D_{m}$ are standard deviations of returns 
also in groups of funds and benchmark, and $n_{\text {fund }}$ as well as $n_{m}$ are sizes of samples.

The $t$-statistic distribution depends on the mentioned sample size and variance ratio within the sample. The null hypothesis about mean returns of funds from the sample equal to the benchmark could be rejected when the absolute value of the $t$-statistic, computed on the basis of the sample is higher than the critical value for the adequate significance level and degrees of freedom calculated as follows:

$$
v=\frac{\left(S D_{\text {fund }}+S D_{m}\right)^{2}}{\frac{S D_{\text {fund }}^{2}}{n_{\text {fund }}^{2}\left(n_{\text {fund }}-1\right)}+\frac{S D_{m}^{2}}{n_{m}^{2}\left(n_{m}-1\right)}}
$$

where $v$ stands for the number of degrees of freedom. In other words, the rejection of the hull hypothesis suggests that the differences between mean returns in the examined samples are statistically significant in the study period. The positive values of $t$-statistic defined by the formula (8) are favourable to the alternative hypothesis about funds outperforming the benchmark. However, the negative values mean underperformance. If there are no grounds to reject the null hypothesis, we may assume that the differences between the means in the analyzed samples are of random character [see Schulz, 2003].

The significance level of returns' variability in individual funds can be examined using one of the tests for variances. In order to include a higher number of samples with unequal size $\left(n_{i}>5\right)$ in the testing procedure for the analyzed entities, we will use an amplification for the F-Snedecor test, i.e. the Bartlett's test of homogeneity of variances, based on the Chi-square statistic [Bartlett, 1937]:

$$
\chi^{2}=\frac{(N-k) \ln \left(S_{p}^{2}\right)-\sum_{i=1}^{k}\left(n_{i}-1\right) \ln \left(S_{i}^{2}\right)}{1+\frac{1}{3(k-1)}\left(\sum_{i=1}^{k}\left(\frac{1}{n_{i}-1}\right)-\frac{1}{N-k}\right)}
$$

where $N$ means the total size of all samples, $k$ is the number of samples, $n_{i}$ is the size of the sample $i$, and $S_{i}^{2}$ means variance in the sample $i$. The above equation contains also $S_{p}^{2}$, which means the pooled estimate for the variance and is calculated as:

$$
S_{p}^{2}=\frac{1}{N-k} \sum_{i}\left(n_{i}-1\right) S_{i}^{2}
$$


In the Bartlett's test it is assumed that the samples come from populations with normal distributions, for which the hypothesis about homogeneity of variances in all sub-populations (individual funds) is tested. The $x^{2}$-statistic follows the asymptotic chi-square distribution with $k-1$ degree of freedom. The calculated value of $x^{2}$ is compared with the critical value from tables of chisquare distribution at the a level of significance [see Diamond and Jefferies, 2001]. The null hypothesis can be rejected at the minimal probability level of 0.05 .

Moreover, in order to present mean returns achieved by individual funds together with the corresponding risk levels in an illustrative way, we will use a graphic tool, namely the so-called risk-performance mapping. The expected return is plotted on the vertical axis and standard deviation, a measure of risk, on the horizontal one. Finally, the measure of dispersion could be a coefficient of variation calculated as a ratio of standard deviation to mean return.

\section{Results and Discussion}

As mentioned before, the study uses the data of Czech, Hungarian and Polish mutual funds. The results will be presented in the form of average annual returns generated by the analysed funds over individual periods as well as sub-periods related to particular cycles in the stock markets. The results of the dispersion analysis will include the values of yearly return and risk. The findings will be presented separately for all of the selected CEE markets.

\subsection{Czech Mutual Funds}

A part of the Czech mutual fund industry is the first market of collective investment investigated in this paper. The number of equity funds within the analysed segment at the end of the study period was 32, whereas the total number of observations is 338 . We measured returns using discrete return, market-adjusted return, Sharpe ratio and Jensen's alpha. The results are presented in table 3 . Moreover, the values of the Welch's $t$-test are included in the lower part of the table.

The analysis revealed that Czech equity funds were on average able to attain positive performance in ten out of sixteen yearly periods; however, the funds from the sample outperformed the benchmark for the segment (see marketadjusted returns in table 3 ) only in several periods (2008-2011 and 20132014). These abnormal returns were observed partly in periods following sharp declines in the local and global securities markets. After including unsystematic risk in Sharpe ratio calculations the positive values were noted for similar periods (2009 and 2013-2015). This was also confirmed by the results for the subperiods referring to market cycles. The two measures mentioned above produced negative results for the total time horizon. The fourth measure - Jensen's alpha ${ }^{1}$ - brought positive results exactly for the half

\footnotetext{
1 The results obtained by using Jensen's alpha should be treated carefully. Out of 338 estimated parameters only 44 (approx. 13\%) were statistically significant for Czech equity funds.
} 
of the yearly periods included in the study. The average annual alphas were slightly positive for the entire time horizon. These overall findings do not provide strong evidence for confirming the thesis about the existence of returns exceeding the benchmark. The measurement of risk level, in turn, done by using standard deviation, produced results showing return volatility relatively lower than benchmark volatility. The values of standard deviation were between 0.02 and 0.07 of the interval, and the mean value obtained for the entire time horizon (0.0404) was the lowest among the three analysed CEE fund markets; by comparison, the standard deviations for benchmark in the total period equalled 0.0573 .

Table 3 Return and risk evaluation for Czech equity funds in given periods and the value of $t$-statistic testing the difference between the returns of mutual funds and benchmark means in the total period under study

\begin{tabular}{|c|c|c|c|c|c|c|c|}
\hline \multirow{2}{*}{ Period } & \multirow{2}{*}{$\boldsymbol{r}$} & \multirow{2}{*}{$R m$} & \multirow{2}{*}{$S R$} & \multirow{2}{*}{ Alfa } & \multirow{2}{*}{$S D$} & \multicolumn{2}{|c|}{ Benchmark* } \\
\hline & & & & & & Return & Risk \\
\hline 2000 & -0.0561 & -0.0332 & -0.2729 & -0.0087 & 0.0282 & -0.0229 & 0.1002 \\
\hline 2001 & -0.1991 & -0.0238 & -0.1568 & -0.0092 & 0.0552 & -0.1753 & 0.0675 \\
\hline 2002 & -0.2292 & -0.3967 & -0.0871 & 0.1243 & 0.0562 & 0.1675 & 0.0617 \\
\hline 2003 & 0.0973 & -0.3334 & -0.0512 & -0.0022 & 0.0340 & 0.4306 & 0.0421 \\
\hline 2004 & 0.0809 & -0.4849 & -0.0855 & -0.0025 & 0.0262 & 0.5658 & 0.0466 \\
\hline 2005 & 0.1376 & -0.2898 & -0.1143 & 0.0021 & 0.0278 & 0.4273 & 0.0455 \\
\hline 2006 & 0.0497 & -0.0290 & -0.1709 & -0.0003 & 0.0262 & 0.0787 & 0.0396 \\
\hline 2007 & 0.0070 & -0.1354 & -0.1408 & -0.0036 & 0.0331 & 0.1424 & 0.0483 \\
\hline 2008 & -0.4731 & 0.0540 & -0.0940 & -0.0135 & 0.0760 & -0.5272 & 0.0974 \\
\hline 2009 & 0.4184 & 0.1165 & 0.0077 & 0.0191 & 0.0592 & 0.3019 & 0.1151 \\
\hline 2010 & 0.0998 & 0.0036 & -0.0121 & 0.0033 & 0.0424 & 0.0962 & 0.0557 \\
\hline 2011 & -0.1560 & 0.1001 & -0.0305 & -0.0001 & 0.0463 & -0.2561 & 0.0494 \\
\hline 2012 & 0.1233 & -0.0168 & -0.0102 & 0.0037 & 0.0326 & 0.1401 & 0.0476 \\
\hline 2013 & 0.1179 & 0.1657 & 0.0055 & 0.0115 & 0.0281 & -0.0478 & 0.0394 \\
\hline 2014 & 0.0589 & 0.1017 & 0.0016 & 0.0058 & 0.0230 & -0.0428 & 0.0266 \\
\hline 2015 & -0.0118 & -0.0220 & 0.0013 & 0.0015 & 0.0414 & 0.0102 & 0.0346 \\
\hline 2000-2003 & -0.1133 & -0.2291 & -0.1222 & 0.0372 & 0.0439 & 0.1000 & 0.0679 \\
\hline 2004-2007 & 0.0644 & -0.2254 & -0.1295 & -0.0012 & 0.0288 & 0.3035 & 0.0450 \\
\hline 2008-2011 & -0.0114 & 0.0694 & -0.0297 & 0.0028 & 0.0555 & -0.0963 & 0.0794 \\
\hline 2012-2015 & 0.0664 & 0.0533 & -0.0003 & 0.0054 & 0.0315 & 0.0149 & 0.0371 \\
\hline 2000-2015 & 0.0074 & -0.0460 & -0.0558 & 0.0097 & 0.0404 & 0.0805 & 0.0573 \\
\hline $\begin{array}{l}\text { The value of } \\
\text { the Welch's } \\
t \text {-statistic }\end{array}$ & -1.2025 & $\begin{array}{c}\text { The numbe } \\
\text { of degree } \\
\text { freedom }\end{array}$ & $\begin{array}{l}e^{2} \\
\text { f }\end{array}$ & sic & $\begin{array}{l}\text { minimal } \\
/ t / \text { to of } \\
\text { :ance lev }\end{array}$ & $\begin{array}{l}\text { itical } \\
\text { in the } \\
\text { of } 10 \%\end{array}$ & 1.7459 \\
\hline
\end{tabular}

Note: * the benchmark for Czech equity funds was PX index.

Source: Own compilation

The value of $t$-statistic for the test of equal means in two populations is 1.2025. It means that Czech mutual funds achieved results lower than the return from the benchmark. However, the lack of statistical significance (compare with the 1.7459 critical value) suggests that these findings should 
be treated with reserve. The study uses a dispersion map for evaluating performance of the analysed financial intermediaries. Figure 1 presents a graph in which the $y$-axis stands for return, and the x-axis represents the values of standard deviation showing risk levels in the total study period. We also provided the values of $\mathrm{X}^{2}$-statistic (the Bartlett's test), which are given in the upper right-hand corner.

Figure 1 Risk-performance mapping for Czech equity funds and the level of homogeneity of variances

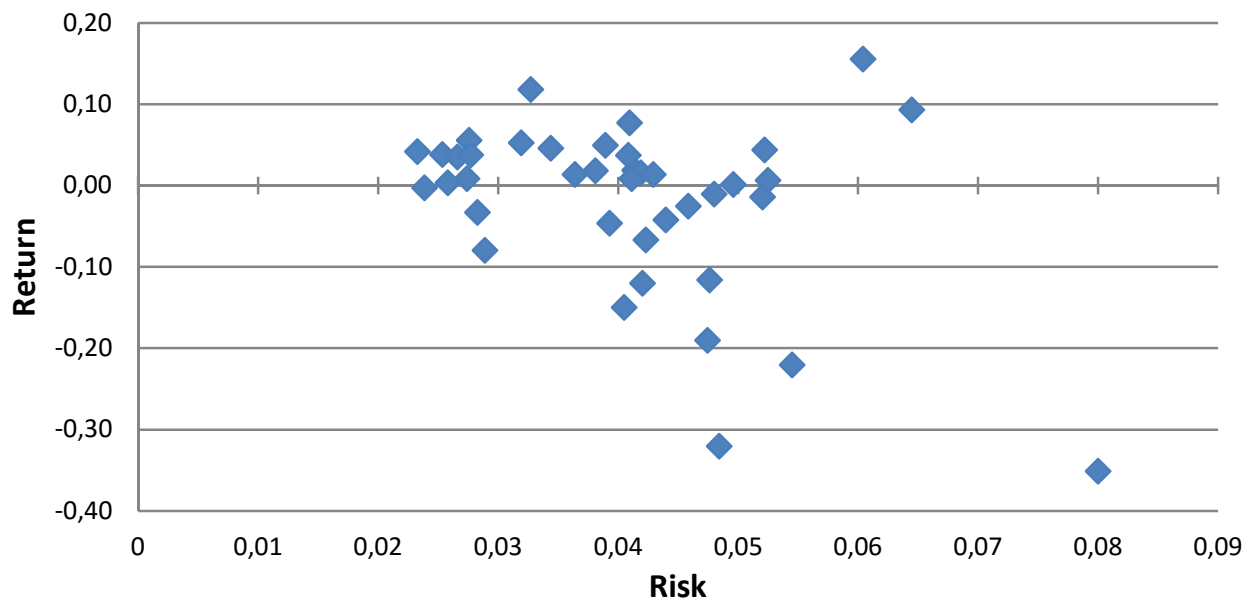

Note: Value of $x 2$ test $=67.1179$; the number of degree of freedom: 37 ; the critical value of significance level $(a=0.05)$ : 52.1923 ; the coefficient of variation $=5.49$.

Source: Own compilation

In the case of Czech equity funds, some entities generate better raw rates of return than their competitors; these rates are obtained at a higher risk level (see figure 1). The reported return dispersion allows for indicating better or worse managed funds. However, at this point, we should refer back to the findings presented in table 3, where the average returns differ significantly from the benchmark (PX). It also has to be noted that the dispersion analysis concerns the average annual performance of all equity funds regardless of their market entrance periods. The value of dispersion measure calculated as a coefficient of variation for Czech equity funds was 5.49 and means high variability.

By comparing the returns' variances of individual funds using the Bartlett's test it is possible to conclude that the dispersion of returns is significant, and the null hypothesis about the equality of variances in subpopulations could be rejected. The value of the calculated statistic $\left(X^{2}=67.1179\right)$ exceeded the theoretical value for the assumed significance level. It means that in the case of Czech mutual funds the variances are heterogeneous. In other words, the returns are characterized by a different level of variability. 


\subsection{Hungarian Mutual Funds}

On the basis of gathered data, we recognized 109 equity funds operated in Hungary at the end of 2015. Within the entire time horizon of the study, we registered 1064 observations depending on the return measure used. The study uses raw return, market-adjusted return, Sharpe ratio and Jensen's alpha. The results of return and risk evaluation for Hungarian entities are shown in table 4.

Table 4 Return and risk evaluation for Hungarian equity funds in given periods and the value of $t$-statistic testing the difference between the returns of mutual funds and benchmark means in the total period under study

\begin{tabular}{|c|c|c|c|c|c|c|c|}
\hline \multirow{2}{*}{ Period } & \multirow{2}{*}{$\boldsymbol{r}$} & \multirow{2}{*}{$R m$} & \multirow{2}{*}{$S R$} & \multirow{2}{*}{ Alfa } & \multirow{2}{*}{$S D$} & \multicolumn{2}{|c|}{ Benchmark* } \\
\hline & & & & & & Return & Risk \\
\hline 2000 & -0.0763 & 0.0513 & -0.5541 & -0.0146 & 0.0353 & -0.1276 & 0.0791 \\
\hline 2001 & -0.1233 & -0.0602 & -0.4978 & -0.0199 & 0.0393 & -0.0632 & 0.0592 \\
\hline 2002 & -0.0530 & -0.1640 & -0.3319 & -0.0124 & 0.0348 & 0.1110 & 0.0715 \\
\hline 2003 & 0.1827 & -0.0223 & 0.1886 & 0.0072 & 0.0306 & 0.2050 & 0.0600 \\
\hline 2004 & 0.2284 & -0.3173 & 0.1305 & 0.0125 & 0.0290 & 0.5456 & 0.0260 \\
\hline 2005 & 0.2371 & -0.1885 & 0.3828 & 0.0134 & 0.0304 & 0.4256 & 0.0819 \\
\hline 2006 & 0.1112 & -0.0695 & 0.0262 & 0.0063 & 0.0385 & 0.1807 & 0.0542 \\
\hline 2007 & -0.0350 & -0.0786 & -0.3680 & -0.0085 & 0.0349 & 0.0435 & 0.0519 \\
\hline 2008 & -0.3394 & 0.1654 & -0.6786 & -0.0535 & 0.0633 & -0.5049 & 0.0845 \\
\hline 2009 & 0.4165 & -0.2656 & 0.2658 & 0.0325 & 0.0616 & 0.6821 & 0.0935 \\
\hline 2010 & 0.1619 & 0.1534 & 0.2253 & 0.0089 & 0.0395 & 0.0085 & 0.0700 \\
\hline 2011 & -0.0998 & 0.1120 & -0.2405 & -0.0144 & 0.0636 & -0.2118 & 0.0704 \\
\hline 2012 & 0.0917 & 0.0131 & 0.0038 & 0.0024 & 0.0393 & 0.0786 & 0.0537 \\
\hline 2013 & -0.0083 & -0.0118 & -0.0781 & -0.0041 & 0.0378 & 0.0035 & 0.0281 \\
\hline 2014 & 0.0747 & 0.1899 & 0.1191 & 0.0018 & 0.0534 & -0.1152 & 0.0458 \\
\hline 2015 & -0.0132 & -0.4705 & -0.0548 & 0.0018 & 0.0507 & 0.4573 & 0.0584 \\
\hline 2000-2003 & -0.0067 & -0.0540 & -0.2689 & -0.0090 & 0.0349 & 0.0313 & 0.0675 \\
\hline 2004-2007 & 0.1268 & -0.1571 & 0.0237 & 0.0052 & 0.0335 & 0.2989 & 0.0535 \\
\hline 2008-2011 & 0.0402 & 0.0502 & -0.0813 & -0.0045 & 0.0571 & -0.0065 & 0.0796 \\
\hline 2012-2015 & 0.0392 & -0.0513 & 0.0004 & 0.0004 & 0.0452 & 0.1060 & 0.0465 \\
\hline $2000-2015$ & 0.0456 & -0.0356 & -0.0497 & -0.0014 & 0.0464 & 0.1074 & 0.0618 \\
\hline $\begin{array}{l}\text { Value of the } \\
\text { Welch's } t- \\
\text { statistic }\end{array}$ & -0.9902 & $\begin{array}{r}\text { The nu } \\
\text { degree o }\end{array}$ & $\begin{array}{l}\text { mber of } \\
\text { freedom }\end{array}$ & 15 & $\begin{array}{c}\text { The minir } \\
\text { value } / t / \\
\text { the signifi } \\
\text { of }\end{array}$ & $\begin{array}{l}\text { critical } \\
\text { obtain } \\
\text { nce level } \\
\%\end{array}$ & 1.7530 \\
\hline
\end{tabular}

Note: * the benchmark for Hungarian equity funds was BUX index.

Source: Own compilation

As we can see, the rates of return on investment in Hungarian equity funds were positive in several periods, depending on the market situation. However, it should be noted that just as in the case of Czech funds, returns outperformed the benchmark only in six out of sixteen yearly periods. This was shown particularly well by market-adjusted return and refers to the years 2000, 2008, 2010-2012 and 2014 and to the subperiods representing market cycles. The two remaining performance measures revealed a relatively strong 
dynamics of market trend related changes in several yearly periods. Fund returns as opposed to equity index experienced lower ups and downs, particularly during drastic market changes. The Sharpe ratio for the average annual return within the entire period under study was generally negative. The values of Jensen's alphas ${ }^{2}$ were positive in nine out of sixteen yearly periods. However, the alphas for the entire time horizon were below 0 . The final findings seem to support the hypothesis concerning the lack of ability to achieve abnormal returns. Moreover, the risk level analysis for the discussed funds done by using standard deviation, showed that the average volatility of fund returns was higher only in three yearly periods (2004 and 2013-2014). Hence, the findings are related with the fact that the portfolios of equity funds, being less diversified than stock index, are characterized by lower variability.

The calculated value of $t$-statistic is lower than the critical value at the minimal level of significance. Hence, there is a lack of evidence to reject the null hypothesis about the equality of funds' returns and benchmark means. The negative value of the Welch's $t$-test corresponds well with the results from table 4 for Hungarian mutual funds, which suggest that funds' returns underperform the benchmark.

The study uses a graphic tool for performance evaluation, which is namely a return-risk map. Figure 2 presents the average annual rates of return and the values of standard deviation for individual Hungarian equity funds in the total study period. This part also presents the findings concerning the level of variances homogeneity.

Figure 2 Risk-performance mapping for Hungarian equity funds and the level of homogeneity of variances

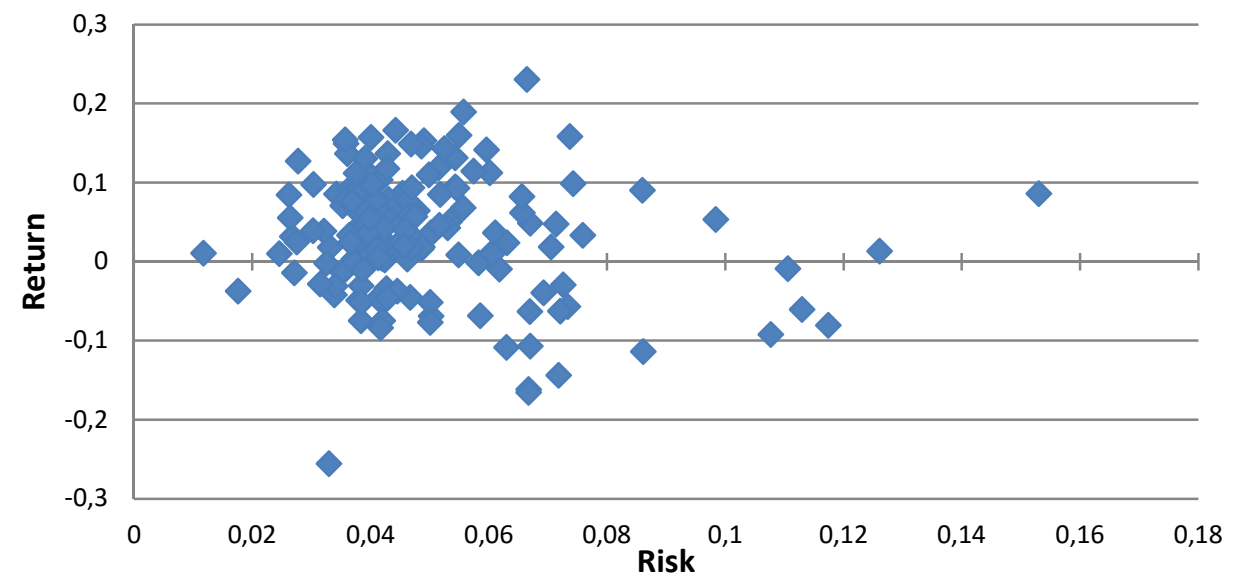

Note: Value of $x 2$ test $=209.2638$; the number of degree of freedom: 145 ; the critical value of significance level $(a=0.05): 174.101$; the coefficient of variation $=1.02$.

Source: Own compilation

\footnotetext{
2 The values of Jensen's alphas should be treated with reserve. Out of 1064 estimated parameters only 153 (approx. 14\%) were statistically significant for Hungarian equity funds.
} 
The average annual performance of individual Hungarian equity funds, both in terms of return and risk, is presented in figure 2 . The results of the analysis show that a small group of funds received higher returns at a relatively limited risk. As mentioned before, the average annual returns were much lower than the returns from the benchmark (BUX). The position of outliers with discrete returns near 0.2 and/or with the risk level above 0.15 results from comparing the average performance of the entities that have different longevity periods. Accordingly, the results should be treated with reserve. The coefficient of variation for Hungarian equity funds returns equals 1.02 and indicates a rather high variability.

The values of $x^{2}$-statistic form the Bartlett's test provided arguments for rejecting the hypothesis about variances equality. This indicates that in relation to Hungarian funds the return dispersion is significant, which means that there is relatively large heterogeneity of variances.

\subsection{Polish Mutual Funds}

The constructed database enabled us to obtain information about equity funds operated in Poland. At the end of the period under study, there had been 153 entities in the market; the total number of observations amounted to maximum 1033 within the entire time horizon. Table 5 presents the average annual values of the measures of return and risk.

As can be seen in table 5, we measured the effectiveness of asset management by using classic raw returns, market-adjusted returns, Sharpe ratio and Jensen's alpha. The performance of Polish mutual funds was positive in the majority of periods. In order to compare the results with the stock index, we used the second of the performance measures. Three out of six yearly periods, in which the analysed entities outperformed the benchmark (WIG), overlapped with upward tendencies in the equity market (2007 and 2013-2014). However, while evaluating performance over consecutive market cycles, we noted that the obtained results always failed to beat the benchmark. The sign preceding the yearly values of Sharpe ratios suggests that after including the differences in risk level, the returns of Polish funds were characterized by a relatively high volatility. However, the mean value of the risk-adjusted returns was negative in the entire time horizon. The values of Jensen's alphas ${ }^{3}$, in turn, were slightly positive in ten out of sixteen yearly periods. The findings concerning the average income generated by Polish funds are in line with the efficient market hypothesis. The measurement risk produced results concerning the volatility of funds' returns. The average annual value of standard deviation, which equals 0.0427 seems to be relatively low, particularly when the average risk form the benchmark is higher. However, the level of unsystematic risk in the analysed sample was generally

${ }^{3}$ The findings obtained by means of Jensen's alphas should be treated carefully. Out of 1033 estimated parameters only 263 (approx. 25\%) were statistically significant for Polish equity funds. 
the highest in the periods of sharp decline and strong growth in the local equity market.

The test for differences between the means indicated that the funds' returns are lower than the potential income from the benchmark (the value of the $t-$ statistic was -0.8004). Nevertheless, these results were statistically insignificant.

Table 5 Return and risk evaluation for Polish equity funds in given periods and the value of $t$-statistic testing the difference between the returns of mutual funds and benchmark means in the total period under study

\begin{tabular}{|c|c|c|c|c|c|c|c|}
\hline \multirow{2}{*}{ Period } & \multirow{2}{*}{$r$} & \multirow{2}{*}{$R m$} & \multirow{2}{*}{$S R$} & \multirow{2}{*}{ Alfa } & \multirow{2}{*}{$S D$} & \multicolumn{2}{|c|}{ Benchmark* } \\
\hline & & & & & & Return & Risk \\
\hline 2000 & 0.1165 & 0.1295 & -0.0866 & 0.0085 & 0.0607 & -0.0131 & 0.0641 \\
\hline 2001 & -0.1430 & 0.0770 & -0.4393 & 0.0008 & 0.0530 & -0.2199 & 0.0712 \\
\hline 2002 & -0.0040 & -0.0360 & -0.1460 & -0.0036 & 0.0475 & 0.0319 & 0.0708 \\
\hline 2003 & 0.3661 & -0.0831 & 0.3944 & 0.0038 & 0.0538 & 0.4492 & 0.0771 \\
\hline 2004 & 0.2142 & -0.0652 & 0.4924 & 0.0013 & 0.0242 & 0.2794 & 0.0264 \\
\hline 2005 & 0.2168 & -0.1198 & 0.2882 & -0.0050 & 0.0372 & 0.3366 & 0.0506 \\
\hline 2006 & 0.4146 & -0.0014 & 0.4917 & 0.0051 & 0.0469 & 0.4160 & 0.0598 \\
\hline 2007 & 0.1049 & 0.0011 & 0.0677 & 0.0019 & 0.0508 & 0.1039 & 0.0600 \\
\hline 2008 & -0.5092 & 0.0015 & -0.9072 & -0.0090 & 0.0654 & -0.5107 & 0.0750 \\
\hline 2009 & 0.4447 & -0.0238 & 0.4124 & 0.0036 & 0.0632 & 0.4685 & 0.0897 \\
\hline 2010 & 0.1670 & -0.0207 & 0.2584 & 0.0023 & 0.0388 & 0.1877 & 0.0470 \\
\hline 2011 & -0.2120 & -0.0036 & -0.5090 & -0.0083 & 0.0467 & -0.2083 & 0.0488 \\
\hline 2012 & 0.1474 & -0.1150 & 0.1828 & -0.0027 & 0.0379 & 0.2624 & 0.0436 \\
\hline 2013 & 0.1010 & 0.0204 & 0.1539 & 0.0006 & 0.0397 & 0.0806 & 0.0458 \\
\hline 2014 & 0.0039 & 0.0014 & -0.0417 & -0.0013 & 0.0298 & 0.0026 & 0.0316 \\
\hline 2015 & -0.0318 & 0.0639 & -0.1290 & 0.0028 & 0.0351 & -0.0962 & 0.0272 \\
\hline $2000-2003$ & 0.1030 & -0.0132 & -0.0338 & 0.0011 & 0.0533 & 0.0620 & 0.0708 \\
\hline 2004-2007 & 0.2252 & -0.0346 & 0.2920 & 0.0012 & 0.0435 & 0.2840 & 0.0492 \\
\hline 2008-2011 & -0.0067 & -0.0121 & -0.1547 & -0.0028 & 0.0522 & -0.0157 & 0.0651 \\
\hline 2012-2015 & 0.0485 & -0.0016 & 0.0300 & 0.0000 & 0.0354 & 0.0623 & 0.0371 \\
\hline $2000-2015$ & 0.0507 & -0.0077 & -0.0070 & -0.0007 & 0.0427 & 0.0981 & 0.0556 \\
\hline $\begin{array}{c}\text { Value of the } \\
\text { Welch's } t- \\
\text { statistic }\end{array}$ & $0 . \overline{-}$ & The & $\begin{array}{l}\text { mber of } \\
\text { ee of } \\
\text { dom }\end{array}$ & 15 & $\begin{array}{r}\text { The min } \\
\text { value } / \\
\text { the sic } \\
\text { level }\end{array}$ & $\begin{array}{l}\text { critical } \\
\text { o obtain } \\
\text { icance } \\
10 \%\end{array}$ & 1.7530 \\
\hline
\end{tabular}

Notes: * the benchmark for Polish equity funds was WIG index.

Source: Own compilation

As mentioned before, the dispersion analysis used the risk-return mapping. Figure 3 presents the average yearly rates of return and the values of standard deviations for individual funds in the total study period. Moreover, the paper presents the results from homogeneity of variances testing. 
The dispersion analysis presented in figure 3 seems to be relatively schematic. Most of the entities achieved slightly positive discrete returns at the average level of risk. Some funds have a marginally higher average performance than their competitors. However, as mentioned before, it was hard to obtain returns exceeding the benchmark, particularly over longer periods of time, which supports the hypothesis about the unachievable abnormal returns. The value of variation coefficient for Polish equity funds was 0.84 and indicates a moderate dispersion.

Figure 3 Risk-performance mapping for Polish equity funds and the level of homogeneity of variances

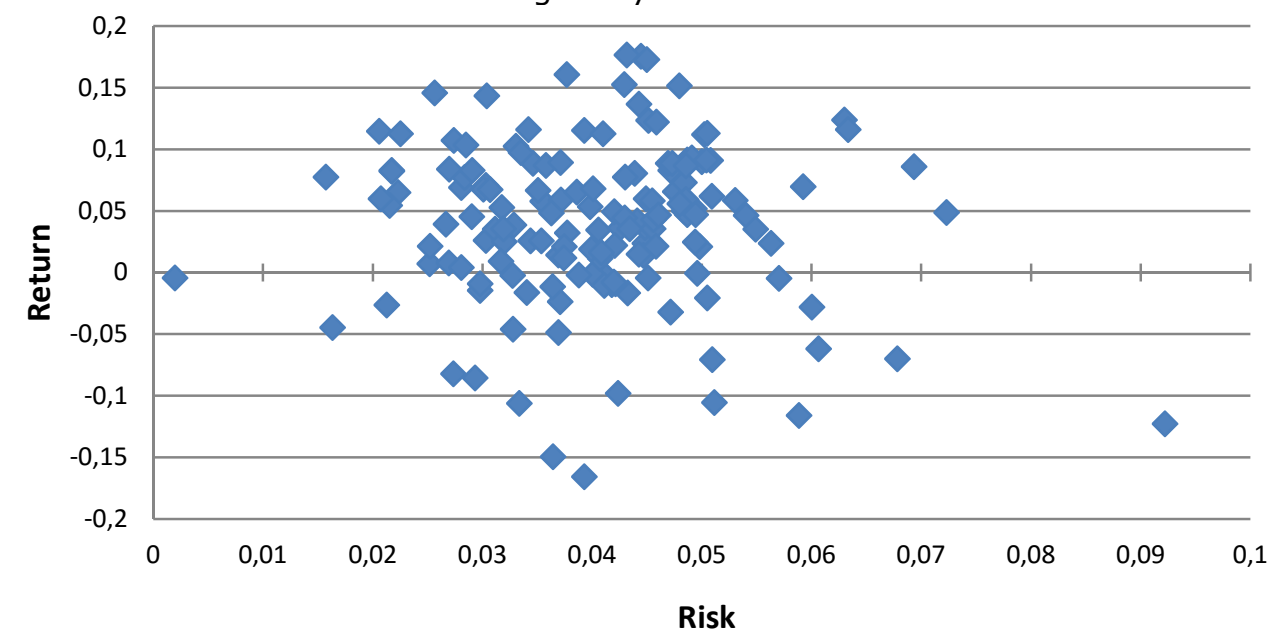

Note: Value of $\mathrm{X} 2$ test $=180.3188$; the number of degree of freedom: 142 ; the critical value of significance level $(a=0.05): 170.809$; the coefficient of variation $=0.84$

Source: own compilation.

The variance homogeneity analysis, conducted in accordance with the approach proposed by Bartlett, provided arguments to reject the null hypothesis about the lack of differences in variations for individual funds. The value of $\mathrm{X}^{2}$-statistic marginally exceeded the critical value for the assumed level of significance. Hence, it could be concluded that the returns achieved by Polish funds are characterised by different variability in the total period under study.

\section{Conclusions}

The financial markets in new EU member states, such as the CEE ones, might be perceived as less efficient. Accordingly, the conclusions concerning the more developed markets, indicating that mutual funds are unable to outperform, may have no application to the emerging markets. These cognitive and practical aspects of analysing the performance of collective investment companies are the reason for addressing the issue discussed in the present paper. 
The aim of the study was to evaluate mutual fund performance on the basis of returns and risk levels. To this end, we used the following selected measures of return mentioned in the reviewed empirical literature: discrete return, market-adjusted return, Sharpe ratio and Jensen's alpha. The measurement of risk, in turn, was done by using the values of standard deviation. Moreover, we employed a graphic method, the so-called risk-return map, for presenting return collated with risk levels, and decided to use statistical hypothesis testing to examine the homogeneity of their variability.

The study sample comprised 294 equity funds (domestic and foreign ones) operated in the Czech Republic (32 entities), Hungary (109 entities) and Poland (153 entities). The time horizon was the 2000-2015 period, with market cycles distinguished in given years. Having analysed the collected data, we noted that mutual funds were unable to outperform their benchmarks in terms of average return. However, the tests provided statistically insignificant evidence for rejecting the hypothesis about equality of return means in mutual funds and applied benchmarks. Furthermore, the level of risk in funds, calculated as volatility of returns, was lower than the mean value of benchmark's standard deviation. The study has also shown that the variability of mean risk-adjusted return depends on the short term market situation. Moreover, we noted that the average annual investment results of funds in the Czech Republic, Hungary as well as Poland in the short periods of upward tendencies in equity markets were, in general, worse than the returns achieved form PX, BUX and WIG index respectively. As for the periods of downward trends in the local securities markets, the funds operated in less liquid markets did not lose as much as the mentioned indices.

The dispersion analysis indicates the existence of individual entities which received higher returns than their competitors at a relatively low level of risk. However, the mentioned results were unable to outperform benchmarks. The assumption about the variance homogeneity of mutual funds was rejected on the basis of tests. The diversity of return variances observed in the case of Czech, Hungarian as well as Polish funds could be due to the fact that domestic and foreign mutual funds were analysed jointly and in the analysed samples of funds there was no distinction between various investment strategies (passive or active). The article is an introduction to the evaluation of mutual funds' effectiveness and provides the basis for further studies and analyses in this area.

\section{Acknowledgements}

The paper was written with financial support from the National Science Centre, Poland (Narodowe Centrum Nauki) - Decision no. DEC-2014/15/D/HS4/01227. Project: "Determinants of Mutual Fund Performance: Managerial characteristics and fund attributes". 


\section{References}

Ankrim, E. M. and Ding, Z. (2002). Cross-Sectional Volatility and Return Dispersion. Financial Analysts Journal, 58(5), pp. 67-73.

Bartlett, M. S. (1937). Properties of sufficiency and statistical tests. Proceedings of the Royal Society of London Series A, No. 160, pp. 268282.

Białkowski, J. and Otten, R. (2011). Emerging Market Mutual Fund Performance: Evidence for Poland. The North American Journal of Economics and Finance, 22(2), pp. 118-130.

Bóta, G. and Ormos, M. (2013). Performance of Hungarian Mutual Funds and the Financial Crisis. In European Financial Systems 2013. Proceedings of the 10th International Scientific Conference, Brno: Masaryk University, pp. 40-46.

Brown, S.J., Goetzmann, W., Ibbotson, R.G. and Ross, S.A. (1992). Survivorship bias in performance studies. The Review of Financial Studies, 5(4), pp. 553-580.

Carlson, R.S. (1970). Aggregate Performance of Mutual Funds: 1948-1967. Journal of Financial and Quantitative Analysis, 5, pp. 1-32.

de Silva, H., Sapra, S. and Thorley, S. (2001). Return Dispersion and Active Management. Financial Analysts Journal, 57(5), pp. 29-42.

Diamond, I. and Jefferies, J. (2001). Beginning Statistics: An Introduction for Social Scientists. SAGE Publications Ltd; 1 edition.

EFAMA (2016). Trends in the European Investment Fund Industry, Quarterly Statistical Release. Available at: http://www.efama.org (accessed June 13, 2016).

Elton, E. J., Gruber, M. J. and Blake, C. R. (1996). Survivorship bias and mutual fund performance. The Review of Financial Studies, 9(4), pp. 10971120.

Erdős, P. and Ormos, M. (2009). Return calculation methodology: Evidence from the Hungarian mutual fund industry. Acta Oeconomica, 59(4), pp. 391409.

Fajtová, J. (2004). Open-ending of closed-End Funds in the CR: price and Discount Reaction - empirical evidence. Czech Journal of Economics and Finance, 54, (1-2), pp. 22-49.

Ferson, W. and Schadt, R. W. (1996). Measuring fund strategy and performance in changing economic conditions. Journal of Finance, 51(2), pp. 425-462.

Filip, D. (2011). The Analysis of Investment Funds Performance in the Czech Republic. Ekonomické listy, 9, pp. 22-39.

Filip, D. (2014). Survivorship Bias and Performance of Mutual Funds in Hungary. Periodica Polytechnica - Social and Management Sciences, 21(2), pp. 47-56.

Friend, I. and Blume, M. E. (1975). The Demand for Risky Assets. American Economic Review, 65(5), pp. 900-922.

Goetzmann, W. N. and Ibbotson, R.G. (1994). Do Winners Repeat? Journal of Portfolio Management, 20(2), pp. 9-18. 
Huij, J. and Verbeek, M. (2007). Cross-sectional learning and short-run persistence in mutual fund performance. Journal of Banking \& Finance, 31, pp. 973-997.

Ippolito, R. A. (1989). Efficiency with Costly Information: A Study of Mutual Fund Performance, 1965-1984. The Quarterly Journal of Economics, 104(1), pp. 1-23.

Isotalo, J. (2014). Basics of Statistics, Independent Publishing Platform, printed by CreateSpace.

Jagric, T., Podobnik, B., Strasek S. and Jagric, V. (2007). Risk-adjusted performance of mutual funds: some tests. South-Eastern Europe Journal of Economics, 2, pp. 233-244.

Jensen, M. C., (1968). The Performance of Mutual Funds in the Period 19451964. Journal of Finance, 23(1), pp. 389-416.

Kaminsky, G. L., Lyons, R. K. and Schmukler, S. L. (2001). Mutual Fund Investment in Emerging Markets: An Overview. The World Bank Economic Review, 15(2), pp. 315-340.

Khorana, A., Servaes, H. and Tufano, P. (2005). Explaining the size of the mutual fund industry around the world. Journal of Financial Economics, 78, pp. 145-185.

Kon, S. J. and Jen, F. C. (1979). The Investment Performance of Mutual Funds: An Empirical Investigation of Timing, Selectivity and Market Efficiency. Journal of Business, 52, pp. 263-290.

Kosowski, R., Naik, N. Y. and Teo, M. (2007). Do Hedge Funds Deliver Alpha? A Bayesian and Bootstrap Analysis. Journal of Financial Economics, 84(1), pp. 229-264.

Lee, J-S., Yen, P-H. and Chen, Y-J. (2008). Longer tenure, greater seniority, or both. Evidence form open-end equity mutual fund managers in Taiwan. Asian Academy of Management Journal of Accounting and Finance, 4(2), pp. 1-20.

Lemeshko, O. and Rejnuš, O. (2015). Performance Evaluation of Equity Mutual Funds in Countries with Emerging Economies: Evidence from BRIC, CEE, sea and MENA Regions. Procedia Economics and Finance, 30, pp. 476-486.

Lintner, J. (1965). The Valuation of Risk Assets and the Selection of Risky Investments in Stock Portfolios and Capital Budgets. The Review of Economics and Statistics, 47(1), pp. 13-37.

Markovic-Hribernik, T. and Vek, U. (2013). Do Mutual Fund Performance and the Abilities of Fund Managers in Slovenia Deviate from Those in Developed Markets? Romanian Economic \& Business Review, 8(1), pp. 130-139.

Markowitz, H. (1952). Portfolio Selection, The Journal of Finance, 7(1), pp. 7791.

Merton, R.C. (1972). An analytic derivation of the efficient portfolio frontier, The Journal of Financial and Quantitative Analysis, 7, pp. 1851-1872.

Modigliani, F. and Modigliani, L. (1997). Risk-Adjusted Performance. Journal of Portfolio Management, 23(2), pp. 45-54.

Mossin, J. (1966). Equilibrium in a Capital Asset Market. Econometrica, 34(4), pp. 768-783.

Naidenova, I. N., Parshakov, P.A., Zavertiaeva, M.A. and Tome, E. (2015). Look For People, Not For Alpha: Mutual Funds Success And Managerial 
Intellectual Capital. HSE Working papers WP BRP 42/FE/2015, National Research University Higher School of Economics.

Olbryś, J. (2009). Conditional market-timing models for mutual fund performance evaluation. Prace $i$ Materiały Wydziału Zarządzania Uniwersytetu Gdańskiego, 4(2), pp. 519-532.

Podobnik, B., Balen, V., Jargic, T. and Kolanovic, M. (2007). Croatian and Slovenian Mutual Funds and Bosnian Investments Funds. Czech Journal of Economics and Finance, 57(3-4), pp. 159-177.

Schulz, M. (2003). Statistical Physics and Economics: Concepts, Tools, and Applications, Springer-Verlag, New York.

Sharpe, W. F. (1964). Capital Asset Prices: A Theory of Market Equilibrium under Conditions of Risk. The Journal of Finance, 19(3), pp. 425-442.

Sharpe, W. F. (1966). Mutual fund performance. Journal of Business, 39(1), pp. 119-138.

Swinkels, L. and Rzezniczak, P. (2009). Performance evaluation of Polish mutual fund managers. International Journal of Emerging Markets, 4(1), pp. 26-42.

Switzer, L. N. and Huang, Y. (2007). How does human capital affect the performance of small and mid-cap mutual funds? Journal of Intellectual Capital, 8(4), pp. 666-681.

Treynor, J. L. (1962). Toward a Theory of Market Value of Risky Assets. Unpublished manuscript. A final version was published in 1999, in Korajczyk R.A. ed. Asset Pricing and Portfolio Performance: Models, Strategy and Performance Metrics. London: Risk Books, pp. 15-22.

Welch B. L. (1947). The generalization of "student's" problem when several different population variances are involved. Biometrika, 34, pp. 28-35. 